ARTICLE

Received 23 Mar 2017 | Accepted 13 Jul 2017 | Published 22 Aug 2017

\title{
Dutch tolerance of torture? CIA extraordinary rendition flights in the Netherlands
}

\author{
Sharise Eski ${ }^{1}$ and Yarin Eski ${ }^{2}$
}

\begin{abstract}
This article explores the (passive) role of the Dutch government in the CIA extraordinary rendition flights (ERFs), also known as "torture flights". It shows why researching ERFs, as a crime of the powerful, is inherently problematic. Afterward, a concise overview follows of European involvement in ERFs and reluctance to investigate them. The article then considers the (known) facts and legal responsibility of the Netherlands regarding the ERFs, concluding with a discussion of the Dutch political discourse of denial of ERF involvement. The main argument is that the discourse of ERF denial fits and reflects the colonial present in which the Dutch government resides, concealing its darkest pages in history while hiding behind its contemporary (political) culture of tolerance and progressiveness.
\end{abstract}

\footnotetext{
${ }^{1}$ Ministry of Economic Affairs, Bezuidenhoutseweg 73, 2594 AC, The Hague, The Netherlands ${ }^{2}$ Liverpool Centre for Advanced Policing Studies, LJMU, Liverpool, UK
} 


\section{Introduction}

"We don't kick the (expletive) out of them (terrorism suspects). We send them to other countries so they can kick the (expletive) out of them" (anonymous US official in Priest and Gellman, 2002: 2).

fter 9/11, the CIA sought to obtain information on possible terrorist activities by applying practices of torturing suspects (Feinstein, 2014). The US tried to circumvent various human rights treaties by extraditing suspects to third countries such as Egypt, Syria, Jordan, Yemen and Uzbekistan. In these countries, human rights protection is poor and thus torture-techniques could be applied during interrogations (Barry et al., 2004; Bader and De Jong, 2006: 14; Satterthwaite, 2007: 6). These extraditions are referred to as CIA "torture flights" (Cobain and Quinn, 2011) or "torture taxis" (Scahill, 2013). Officially they are called extraordinary rendition flights (ERFs) comprising the transfer of an individual to a country where (s)he will be interrogated on terrorists acts they (may) have been responsible for, or in some way, involved in; as distressing is that the individual has no possibility of a legal proceeding to challenge the transfer (Boon et al., 2010). According to the non-refoulement principle, refugees are protected against being forcefully returned to a country where they have reason to fear persecution and torture (UNHRC, 1977). This principle is guaranteed either implicitly or explicitly in several treaties such as the Convention Against Torture and Other Cruel, Inhuman or Degrading Treatment or Punishment (CAT) and the International Covenant on Civil and Political Rights (ICCPR). However, this principle has been circumvented by the US and host countries participating in ERFs through "diplomatic assurances" that the detainee will not be ill-treated (Van Boven, 2002: 30-42; EP, 2012: 51). Circumventing human rights through ERFs is typical of the War on Terror, making it, according to Said (2003: 39), "the most reckless war in modern times", in which "[i]t is all about imperial arrogance unschooled in worldliness, unfettered either by competence or experience, undeterred by history or human complexity, unrepentant in its violence and the cruelty of its technology".

Since 4 October 2001, when the NATO allies met and agreed to take measures, including allowing overflights and access to airfields, for stronger international cooperation in the War on Terror, ERFs have increased in number (NATO, 2001). Consequently, the CIA had to collaborate with other countries (Marty, 2007), because the use of aircrafts depend on using other nations' airspace and airports (for example, for refuelling). Therefore, other governments must be (passively) involved in ERFs. This involvement has increasingly come under scrutiny as the involved governments may be complicit in torture (Blakely, 2011; Cordell, 2017). The Netherlands is not listed as a participating state in ERFs (OSJI, 2013) and seems to comply with several torture prohibition and human rights treaties, such as the European Convention for the Protection of Human Rights and Fundamental Freedoms (ECHR). Nonetheless, there were at least 27 ERFs since 9/11 making use of Dutch territory (Amnesty International (AI), 2006a; Fava, 2006; Van Boven, 2002). The Dutch government still denies (to have any knowledge of) its involvement.

Adopting a language that speaks of "extraordinary rendition (flights)" characterizes the War on Terror, and on a deeper level, the colonial present (Gregory, 2010). This contribution will explore how we ought to understand the (passive) involvement of the Dutch government in that colonial present. First, we will explain why researching the CIA's Extraordinary Rendition
Programme (ERP), of which ERFs are part, is inherently problematic. Second, we will provide a concise overview of European involvement in ERFs and reluctance to investigate. Third, we will consider (known) facts and legal responsibility of the Netherlands regarding the ERFs. Afterward, we will scrutinize the Dutch political discourse of denial (Cohen, 2002) of ERF involvement, followed by a discussion.

\section{Extraordinary flights, secrecy and criminological research}

The very fact that ERF documentation is mostly (kept) secret is an intrinsic issue, as evidence is unavailable, and if available, it is predominantly (considered) speculative (Brysk and Shafir, 2007; Efrat, 2015). Still, if anything, that unavailability and speculation indicate that it is forbidden knowledge that governments prefer to be (kept) secret, whereas it should be made transparent for investigation, or at the very least, shared publicly (Kempner et al., 2011). Logically, that unavailability and speculation pose challenges for researching ERFs as a state crime (Tombs and Whyte, 2003). Consequently, we cannot provide a full picture of the ERFs and Dutch involvement, because accurate information can only be given by authorities and other organizations that remain reluctant to provide such information; if only because they are not investigated and/or not ordered by the Dutch government to share such information, revealing a reluctance of the Dutch government itself. Giving an accurate overview is further complicated because, next to the CIA, more agencies have been involved such as the US Department of Defense and the FBI (Mayer, 2005; Messineo, 2009). Therefore, we have taken on board recommendations to utilize publicly available flight data and other relevant data on known and suspected ERFs to evidence their existence, and document their characteristics (Raphael et al., 2016; Cordell, 2017). That information shows that a significant amount of individuals have been sent to third countries, of which some were detained at CIA "black sites"1 (Satterthwaite, 2008), and despite estimation differences, there seems to have been an increase in the number of observed cases (Brysk and Shafir, 2007; Efrat, 2015; Raphael et al., 2016). However, as AI (2006a, b) points out, flight records do not include all of the stops a plane makes during a trip away from US airspace. Neither is all relevant air traffic registered, meaning flight data is not representative of the number of ERFs because case details of flights are not provided due to the secret nature of ERFs. Data on ERF landings at Dutch airports are most likely incomplete, and we, therefore, also studied reports of non-governmental organisations (NGOs), (critical) media reports and documentaries, and, especially for our scrutiny of the political discourse, documented (official) responses coming from the political domain (Brysk and Shafir, 2007; Blakeley and Raphael, 2013; Brooks, 2016; Raphael et al., 2016; Cordell, 2017).

\section{European involvement in ERFs}

ERFs depend on other nation states' assistance (Nowak, 2008), making it highly unlikely that of the 54 countries that covertly helped/are helping the US by allowing ERFs through and on their territory (OSJI, 2013), not one of them was European (Marty, 2007; Bakowski, 2012). This is even more unlikely, because 19 NATO allies, including the Netherlands and other European states, agreed to the eight measures to contribute to the war against terrorism (NATO, 2001). Evidence provided by Eurocontrol, the US Federal Aviation Authority, and data from the Polish Air Navigation Services Agency (PANSA) supports the idea that European states must have played a role (The Rendition Project, 2010a; Blakeley; 2011; Blakeley and Raphael, 2013; Raphael et al., 2016). However, the USA and its partner 
governments have remained unwilling to provide official investigators with information on flight schedules, landings and transfers, due to reasons of national security (OSJI, 2013). So, "to date, the full scale and scope of foreign government participation-as well as the number of victims-remains unknown" (ibid. 5).

This does not mean there is no information available. Official reports from the Egyptian government stated that 60-70 detainees had been transferred to its custody between September 2001 and May 2005 (Waterman, 2005). Investigative journalists have reported that 4 years after $9 / 11$ over 70 detainees have been subjected to extraordinary rendition (Priest and Gellman, 2002). Other sources estimate 100-150 transferees (Mayer, 2005), and some even speak of several thousand ERF cases (Center for Human Rights and Global Justice ((CHRGJ), 2014)). More recent findings indicate that over 400 suspicious flights have landed in 81 countries worldwide since 9/11 (Blakeley and Raphael, 2013). As for Europe, around 1254 CIA flights had taken place in European airspace between 2001 and 2005 (Fava, 2007). Fava stated that "[t]he routes for some of these flights seem to be quite suspect [...] they are rather strange routes for flights to take. It is hard to imagine [...] those stopovers were simply for providing fuel" (Sturcke, 2006-online).

Concrete European involvement is evidenced by the Abu Omar case, in which several Italian policemen and CIA agents kidnapped Usama Mostafa Hassan Nasr who was subsequently rendered in the Gulfstream IV N85VM to Egypt via Aviano Airbase in Italy and then Germany. He ended up in Egypt where he was held at two different detention sites and subjected to numerous forms of torture, making Italy complicit in torture (The Rendition Project, 2002: 10; Messineo, 2009). Another case is that of the German Muhammad Zammer, who travelled from Germany to Morocco where he got arrested and flown to Syria; there is evidence that the German government provided Zammer's travel plans to US officials (Hawkins, 2005: 252-253; AI, 2011). In particular Poland has played an active role in several ERFs. After serious allegations, Polish politicians were no longer able to lie about CIA prisons existing in Poland, after which the policy of denial was changed into attempting to justify their existence by reasons of necessity, national interest and the need for international cooperation with the US authorities and intelligence (Bodnar and Pacho, 2012). Specifically regarding Polish involvement in ERFs, PANSA flight data showed that CIA registered planes landed in Poland, which led the European Court of Human Rights (ECtHR) to rule that Poland was a significant enabler for the CIA using Polish airspace and airports, and thus complicit as it disguised movements of ERF aircrafts and provided logistics and services, including special security arrangements and special landing procedures (ECtHR, 2014a, b).

In 2012 the European Parliament (EP) urged the European member states to investigate their involvement in ERFs (EP, 2012), nevertheless, most European countries have refused participation, are merely denying and not carrying out inquiries (Marty, 2007: 62), or are claiming non-disclosure and omitting investigations because of "state secrecy" and "national security" reasons (EP, 2012: 10). ibid. 51). In reaction to that European reluctance, and after the ruling on Poland's complicity in the CIA's ERP, the EP announced in February 2015 that it would resume inquiries into the extent of the CIA's extraordinary rendition activities in Europe. Hesitant European countries that are not starting judicial investigations into their role in the CIA programme have been urged to investigate and publish the results (EP, 2015; Raphael et al., 2016). So far, only Germany, Italy and Spain have investigated their ERF involvement, of which the case findings remain unavailable (Boon et al., 2010: 279-280). To date, no such investigation has taken place in the Netherlands, despite compelling known facts.

\section{Known facts about ERFs and complicity of the Dutch state} Overflights and landings in the Netherlands. Human Rights Watch (HRW) alleged that by denying asylum to Muhammed Abu Farsan, the Netherlands violated his rights against unlawful return by transferring him to Sudan (where he held a passport) from where he was sent to Libya to be tortured during CIA interrogations (2012: 111-115). There is, however, no clear evidence (available) that Dutch state officials were indeed aware of the possible transfer to Libya, meaning it is unclear whether the officials actively participated in an unlawful transfer. Besides that allegation, and as far as is known, the Netherlands accommodates no "black sites" for secret detention on their territories (ECtHR, 2014a, 2014b,; Rafael et al., 2016), nor have any Dutch state officials been involved in ERP/ERF-related arrests or transfers, sent to other countries to torture, or provided information that would lead to torturous interrogations (UNHRC, 2010; AI, 2010: 34).

Nonetheless, regarding ERFs, it has been claimed that the "[f] lights of the CIA come to [the Netherlands] for decades now. [...] We always say we know about nothing" (anonymous: former employee of Dutch intelligence services in Alberts, 2005-online). Aviation specialist, Chris Yates, explains that Dutch airspace must have been used by the CIA of which Dutch government must have been aware:

Most governments are consciously blind: what is in an airplane that lands and leaves from an airport is for them no cause of concern. They could get that information, but rather do not want to know. [...] Such an approach gives governments a certain deniability (ibid.).

ERFs appear to have been permanently operated by the CIA through shell companies, of which Presidential Aviation is an example; its planes used Dutch airports frequently (AI, 2006a: 28). Path Corporation also acts as a CIA shell company, and had on 16 November 2005 its De Havilland DHC8-315B type N505LL, coming from Azerbaijan, via Istanbul airport, to land at Schiphol Airport (Fava, 2006: 15). The then Ministry of Transport, Public Works and Water Management confirmed the landing at Schiphol, stating that the airplane left for Iceland on 17 November 2005 to an "unknown destination"; its flight plan stated it was a "non-scheduled" flight (Alberts, 2005).

In 2005, a list provided by the Icelandic air traffic management unit was mentioned on Dutch television; CIA flights were registered leaving Keflavík International Airport in Reykjavik (Zembla, 2005). In total, at least 27 overflights were made through Dutch airspace by CIA-registered planes. Allegedly, most of those flights were operated by the airplane Gulfstream $\mathrm{V}$ jet with the registration N379P which is one of the more notorious ERF planes (Fava, 2007). It transferred Ahmed Agiza and Mohammed al-Zari from Sweden to Egypt in 2001 who were detained and tortured for several months in Egypt (The Rendition Project, 2010b). Six ERFs used Rotterdam/The Hague Airport but it remains unclear whether there were persons aboard and why those planes arrived there. Philippe Domogala, a former air chief who monitored the flights through Dutch airspace, mentioned that various ERFs from Washington to Frankfurt must have crossed Dutch airspace (Zembla, 2005). It is, however, difficult to discover who was aboard the planes due to the unclear purpose of the flights (ibid. at 0:02:58). For example, the N505LL is a civil plane, for which, Domogala explains, it is only necessary to provide the number of passengers aboard and not the names. Therefore, Domogala states, the current aviation regulations make it easy not to disclose passenger details, while CIA-planes can easily change their registration in the US (ibid. 0:37:00), 
which complicates any possibility of a hosting nation to justify inspection.

Airplanes N505LL and N379P were not the only suspect planes using Dutch (aerial) territory. Since 2002, several alleged CIAplanes arrived at Dutch airports (Fava, 2006): Amsterdam, Groningen and Rotterdam. Next to the De Haviland, the Gulfstream III N829MG (later re-registered as N259SK) arrived on 20 July 2002 at Schiphol and left for Bangor (USA) the next day (ibid. 51). This airplane was used for the deportation of Maher Arar, and had frequently landed at Dutch Airports (Alberts, 2006). On April 8, 2003, it arrived again at Schiphol, leaving the next day to Sweden, landing multiple times at Schiphol and once at Groningen Airport. The Groningen Airport warden, $\mathrm{Mr} \mathrm{O}$. de Jong, could not provide any information on that landing because of "secrecy", and additional information is not registered, stating, "as long as they pay, that's most important for us" (ibid. online).

Out of the known 15 arrivals in the Netherlands, on 22 September 2002, 18 May 2005, 21 July 2005 and in August 2005, the Gulfstream V N1HC, another alleged CIA airplane, landed specifically at Schiphol Airport and at Rotterdam/The Hague Airport. Logs of the N1HC's flight history show that it made frequent use of Dutch Airports in the months November and December in 2005, and in February in 2006 (Fava, 2006: 39):

\begin{tabular}{|ll}
\hline Departure & Arrival \\
Amsterdam (Netherlands) & Rotterdam (Netherlands) \\
Rotterdam (Netherlands) & Bangor (USA) \\
White Plains (USA) & Rotterdam (Netherlands) \\
Rotterdam (Netherlands) & Frankfurt (Germany) \\
Frankfurt (Germany) & Rotterdam (Netherlands) \\
Rotterdam (Netherlands) & New York (USA) \\
New York (USA) & Rotterdam (Netherlands) \\
Rotterdam (Netherlands) & Bruxelles (Belgium) \\
Bruxelles (Belgium) & Rotterdam (Netherlands) \\
Rotterdam (Netherlands) & Amsterdam (Netherlands) \\
Amsterdam (Netherlands) & Zurich (Switzerland)
\end{tabular}

Date. $09 / 08 / 2005$ $09 / 08 / 2005$ $01 / 11 / 2005$ $02 / 11 / 2005$ $14 / 12 / 2005$ $15 / 12 / 2005$ $08 / 02 / 2006$ $08 / 02 / 2006$ $09 / 02 / 2006$ $09 / 02 / 2006$ $09 / 02 / 2006$
Other CIA aircrafts were registered under N829MG, N1HC and N505LL; all used Dutch Airports (Fava, 2006: 51). Remarkable was the unwillingness of the European Union's anti-terrorism coordinator, Gijs de Vries, to assist during the inquiry, which made him suspect of withholding information and denying (access to) information for investigation purposes (Trouw, 2007).

Despite ERF landings at and overflights over the Netherlands, Dutch authorities and governmental representatives did and still do not provide clarity about the reasons for (non-interference in) ERFs taking place on Dutch territory. The question, therefore, becomes to which extent there has been a "duty to investigate", as Maxime Verhagen, Dutch Minister of Foreign Affairs 2007-2010, referred to (Senate, 2009: 2-4). If the government had a duty to investigate but did not comply, is the Dutch government (passively) complicit in ERFs, and thus, in practices of torture (cf. Modvig and Jaranson, 2004)?

State responsibility and complicity in torture. The Netherlands complies with the eight NATO measures to expand the options available in the campaign against terrorism (Marty, 2007: 19), implying awareness of ERFs, especially because two of those measures are: (a) providing blanket overflight clearances for the USA' and other Allies' aircrafts for military flights related to operations against terrorism and (b) providing access to ports and airfields on NATO territory, including for refuelling, for the USA and other Allies for operations against terrorism (NATO, 2001). Given the known facts, complicity of the Netherlands in torture becomes likely, because it failed to fulfill obligations according to the CAT, ICCPR and the ECHR; especially regarding obligatory investigations into credible claims about ERFs over one's sovereign territory and (not) intervening in ERFs that used Dutch airspace and airports to, for example, refuel or crew changes (UNHRC, 2010: 130). Failing to investigate constitutes a violation of those obligations, according to the UK Joint Committee on Human Rights (2006). Providing overflight clearances and access to airfields incriminates the Netherlands, because allowing overflights of individuals to secret detention sites or to face extensive interrogation techniques may engender the responsibility of a passive state and may amount to providing assistance, which constitutes state complicity (Venice Commission, 2006: 32-35).

Passiveness of a state could mean "omission" (e.g., failure to investigate) as codified in article 2 of Articles on Responsibility of States for Internationally Wrongful Acts (ASR), which, with the breach of international obligations regarding torture, constitutes an international wrongful act. Based on article 1 ASR, such an act is the direct responsibility of a state. So, the Dutch government has a duty to refrain from human rights violations and a duty to take necessary measures within its powers to secure the rights of individuals within the territory of that state by not allowing overflights transferring individuals to third states where secret detention and exposure to torture occurs. According to article 16 ASR, by providing arrival options on Dutch territory to refuel or change crew, the Netherlands is complicit if it aids or assists another state in an internationally wrongful act by the latter and if it does so with the knowledge of the circumstances of the international wrongful act (AI, 2006b; Venice Commission, 2006).

Given the fact there was widespread reporting on the involvement of European states in ERFs, flight records, NGO reports, and individual cases that were brought before the ECtHR that showed involvement of European states in the renditions operations (UNHRC, 2010), it seems that there was or at least, should have been a level of Dutch governmental knowledge of ERFs as well as the ERP itself. Moreover, given the observations of the De Havilland/N505LL and Gulfstream V N1HC landings at Dutch airports, November 2005 to February 2006 (Fava, 2006) and inquiries by Socialist Party Member, Harry Van Bommel, about Dutch involvement in ERFs on 30th December 2004, show that the government was (officially made) aware of ERFs. Finally, regarding "aid or assistance" under article 16 ASR, the Netherlands failed to prevent ERFs taking place through its sovereign airspace, which makes the Dutch government complicit through aiding/assisting ERFs. Although the International Court of Justice (ICJ) ruled that complicity always requires pro-activity/positive action to furnish "aid or assistance" under article 16 ASR (2007: 218-219), if the Netherlands did not object to the ERFs taking place (which the frequent arrivals and departures of, for example, De Havilland/N505LL and the Gulfstream V N1HC strongly indicate), complicity is imminent considering legal doctrine that suggests that misconduct may consist of action and omission (Aust, 2013: 227).

International aviation law and complicity in torture. Referring to the 1944 Civil Aviation Chicago Convention, Minister of Foreign Affairs from 2003-2007, Ben Bot, argued it was not necessary for airlines to provide prior information about passengers and cargo to authorities (TK, 2005d: 1946). He implies there was no information available for concrete indications on which Dutch authorities would have had to act. To this point, what the cargo was and which destinations the several ERFs had, remains unknown (to the wider public). However, the Dutch government, as any government, is expected to carry out 
inspections according to article 3 of the Chicago Convention by making distinctions between state aircrafts and civil aircrafts. Bot explained that the involved aircrafts were civil aircrafts, limiting the possibilities for Dutch government to investigate. A civil aircraft, that is non-scheduled, may fly over another state's territory and land on that territory for non-traffic purposes such as refuelling, without obtaining prior permission. Only a flight plan is required, according to article 5 of the Chicago Convention. This limits sovereignty of a state with regards to civil aircraft. However, as each host state has complete and exclusive sovereignty over the airspace above its national territory (article 1 Chicago Convention), it is forbidden for state aircrafts to fly over the hosting nation when no authorization has been given, either by special agreement or otherwise provided (article 3c Chicago Convention). Even under customary international law, which gives a state aircraft additional immunity, authorization is still needed from the host state for the state aircraft to enter another sovereign state's airspace (Venice Commission, 2006: 22). Once granted permission, the state aircraft cannot be searched or seized, which would block the possibilities for the Netherlands, for example, to inspect it (ibid.).

The US presents its ERF planes as civil aircrafts to avoid necessary prior authorization (UK House of Commons Foreign Affairs Committee, 2009: 26). However, they carry out a state function transferring prisoners. Although there is no definition of "state aircraft" in the Chicago Convention, a "state aircraft" is an aircraft under control of the state and is being used for stateintended purposes (Diederiks-Verschoor, 1997: 34), implying a civil aircraft could become a state aircraft if it is used for the specific purposes as mentioned in article 3(b) of the Chicago Convention, meaning the aircraft's status should be determined by which function it has (Milde, 2008: 482). The ERF planes presented themselves as civil planes but had state-intended purposes for which authorization for overflight was given, which is in breach of article 3 (c) of the Chicago Convention; the Netherlands should have demanded their landing. Moreover, if a contracting state uses civil aviation, for any purpose that is inconsistent with the aims of the Chicago Convention (Venice Commission, 2006: 22), such as violating human rights, the Netherlands should have ordered airplanes to land. Furthermore, if a state plane presented itself as being a state plane and obtained overflight permission but did not disclose its mission, the Netherlands should have contended that the flag state violated its international obligations (ibid.). Moreover, article 16 of the Chicago Convention does not require "reasonable grounds" to search an aircraft after it has landed. Without unreasonable delay, the aircraft can be searched and its documents (for example, passenger lists) inspected. If the captain then claims it is flying a state aircraft, which would principally grant immunity to the plane, this will then constitute an abuse of civil aviation (Article 4 Chicago Convention), which also should have led to inspections at Dutch airports.

The Netherlands also should have interfered with a civil aircraft in flight on which the passengers' safety is jeopardized (article 3 Tokyo Convention), wherein the jurisdiction of the host state would prevail (Shubber, 1973: 53). The host state then, according to article 4 Tokyo Convention, and reaffirmed by the $\mathrm{EP}$, inspections on board should be carried out in the name of human rights protection (2006: paragraph 209) guaranteed by the ECHR, the ICCPR, the CAT and the Convention for the Protection of All Persons from Enforced Disappearance; no European member state is (able to argue it is) barred by the Chicago Convention or the Tokyo Convention to interfere with an aircraft (2006: 26). Bot's statement regarding how jurisdiction of the registration country state applies to the aircraft as long as it is "in flight", is correct (TK, 2007: 1385); however, he ignores the duty to inspect according to its positive obligations concerning the protection of human rights.

Despite provided known facts and key legal possibilities to inspect several ERFs from November 2005 until February 2006, the Dutch government performed no inspections and remains unwilling to learn more about its role by taking responsibility to investigate, and instead, provides a political discourse of ERF denial.

\section{The Dutch political discourse of ERF Denial}

The Dutch government behaves similarly to how the Polish government did previously: fully denying ERP/ERF involvement; after strong allegations though denial was no longer possible for the Polish government (Bodnar and Pacho, 2012). The Dutch ERF denial seems to come forward from, as Herman and Chomsky (2010) would explain, a (political) elite interest in controlling media to eventually control public debate and dissent from, in this case, Dutch complicity in torture. Dimitriu (2013: $563,565)$ stated that "the Dutch managed to stay distanced from torture accusations [and that...] the nature of these incidents proved to be relatively harmless". We challenge that (rather naive) conclusion, and will consider the political distancing from torture accusations (narrated by politicians who were part of the Dutch cabinet) as a political discourse of official denial (Cohen, 2002: 101-116) of ERF involvement, sustaining and sustained by the colonial present (Gregory, 2010, 2004). That discourse consists of four subsequent phases from December 2004 until June 2009: (1) narrating unawareness and unavailability of facts, (2) accepting critique on (narrating) such unawareness and unavailability, (3) silencing dissenting politicians and (4) normalizing plausible deniability.

Unawareness and unavailability of facts. The Dutch political discourse of denial has been challenged (unsuccessfully to this point) by opposition politicians. In particular Socialist Party member Harry van Bommel asked stridently about Dutch involvement in ERFs, starting 30 December 2004, when he confronted Bot:

Have prisoners also been picked up in the Netherlands? If so, who are they and where have/has he or she been transported to? Did the vessels make any stopovers in the Netherlands? If so, where and when? Where did the vessel (s) go to and why have you given permission for it? (TK, 2005f: 2091)

Bot replied on 24 February 2005, claiming he had received no confirmation those transfers and flights Van Bommel refers to took place and to Bot's knowledge there have been no stopovers in the Netherlands either (ibid. 2092). Two weeks later, 11 March 2005, Van Bommel asked detailed questions about a specific aircraft associated with the CIA and undertaking ERFs. A Gulfstream registered under N379P and N44982 appeared to have arrived at Schiphol Airport Friday 2 May 2003, flying in from Frankfurt, and owned by both Premier Executive Transport Services and Keeler and Tate management (TK, 2005g: 3147). Bot denied knowledge:

According to Schiphol Airport, a Gulfstream with registration number N379P never arrived 2 May 2003. It's not known to me whether Premier Executive Transport Services is the owner of a Gulfstream with registration number N379P. This company is not registered at the Dutch Civil Aviation Authority, and therefore does not possess a landing permit. [...] It is not known to me 
whether a Gulfstream with registration number N379P provided services to the American Ministry of Defence. The company Keeler and Tate Management is not registered at the Dutch Civil Aviation Authority, and therefore does not possess a landing permit. As far as can be checked, the Gulfstream with registration number N44982 has not arrived in the Netherlands (ibid. 3184).

Van Bommel also asked whether any agreements have been made between the American government and European countries for use of their airports when transporting suspects of terrorism and to what extent and why these agreements may be (kept) secret. Once more, Bot claimed to know nothing about such agreements (ibid.). In November 2005, Van Bommel and Bert Koenders of the Dutch Labour Party (PvdA) requested Bot to investigate Dutch involvement in ERFs (Trouw, 2005a), yet no concrete actions followed, as it was claimed that the Dutch Air Traffic Control's had no information about the vessels' purposes (Volkskrant, 2005b).

In claiming that key information was not (made) available and justifying political unawareness of available information on ERFs, as well as by very specifically detailing there was no legal obligation to inspect, appearing to act "lawful but awful" (Passas, 2005), Bot narrates ERF non-involvement and non-complicity in torture, ultimately protecting "a system that does not respond to civilian leadership" (Brooks, 2016: 351). That system revealed itself when Europe confronted the US in December 2005 with its CIA ERP and ERFs.

Accepting critique. Monday 5 December 2005, former United States Secretary of State, Condoleezza Rice, was questioned by European ministers about ERFs in Europe (Die Welle, 2005). Rice responded that the USA did not use airspace or airports of any country for the purpose of transporting a detainee to a country where (s)he will be tortured (MERLN, 2005). However, at the same time, she did not deny the existence of transfers; she merely mentioned that the USA neither tortured nor exposed individuals to torture (Volkskrant, 2005a). The next day, Van Bommel filed another set of questions to Bot for clarification on a list of 300 CIA flights using European airspace (TK, 2005a). Bot persisted that he had no clear indications that Dutch airspace was used for illegal transfers of prisoners by the CIA or other American governmental institutions. Regarding the answers Rice gave about (allegedly) illegal detention facilities outside of the USA, Bot claimed that these were "not satisfactory" and he announced intent to engage in a "heavy discussion" with her during a NATO meeting in Brussels on Wednesday 7 and Thursday 8 December 2005 (NATO, 2005; Volkskrant, 2005a). Bot's reactions reflect the political discourse of ERF denial in which he turns defensiveness into partially acknowledging their criticism (Cohen, 2002: 102) to satisfy critical politicians, but without confirming their critique, nor acknowledging complicity.

In 2003, the Dutch government offered its assistance to a USled effort in Afghanistan, however, "intense public opposition to torture led Dutch political leaders to fear they would face domestic backlash if their army helped apprehend al Qaeda or Taliban members who then ended up at Guantanamo Bay" (Johnson et al., 2016: 125). Two years later, that fear disappeared. At the NATO conference dinner Wednesday 7 December 2005, Rice explained to EU representatives that the US respects the rights of suspects of terrorism. Present at the dinner were Bot and Jaap de Hoop Scheffer who was the then 11th Secretary General of NATO from 2004-2009, and who preceded Bot as Dutch minister of Foreign Affairs from 2002-2003. De Hoop Scheffer explained that Rice "cleared the skies" about, among other concerns, ERFs (Trouw, 2005b). Bot stated he was "very satisfied" about the assurances Rice gave. The next day, 8 December 2005, NATO ministers agreed to expand the International Security Assistance Force (ISAF) in South Afghanistan in 2006 (TK, 2005b; Parlement en Politiek, 2006). Bot, together with the then Minister of Defence, Henk Kamp, and Minister of Development Coordination, Agnes van Ardenne, requested on 22 December 2005 to contribute Dutch soldiers to ISAF in South-Afghanistan (Bot et al., 2005), which was approved by Parliament in February 2006; over a 1000 Dutch soldiers (eventually 2000) were sent to the Afghan province Uruzgan (Dimitriu and De Graaf, 2010).

The politics behind the ISAF exemplify the inner workings of a global network of "private military contractors, politicians and the media [which] present[s] a disturbing picture of the level of collusion between institutions, and an understanding of the systematic nature of torture and its cover-up" (Brooks, 2016: $352)$. That network produces " $t]$ he colonial present $[\ldots]$ through geopolitics and geo-economics [...] set in motion by presidents, prime ministers and chief executives, the state, the military apparatus and transnational corporations" (Gregory, 2004: 16). The political narrative of being unaware and having no available facts, in this case about ERFs, as well as (fabricated) political acceptance of critique should not "blind us to the banality of the colonial present and to our complicity in its horrors" (ibid.). Critical, dissenting politicians can prevent such society-wide blindness, if they are not silenced.

Silencing dissenting politicians. On Friday 9 December 2005, both Van Bommel and Krista van Velzen, also a Socialist Party member, filed questions to Bot and the then Minister of Transport, Public Works and Water Management, Sybillia Dekker, regarding new information broadcast on Dutch television about CIA flights using Dutch airports; apparently, Rotterdam/The Hague airport as well as Saint Martin Princess Juliana International Airport have been used multiple times for ERFs (TK, 2005c). ${ }^{2}$ Bot confirmed there were six different types of aircrafts that arrived at Rotterdam/The Hague Airport of which the cargo was unregistered (TK, 2005d). He declared:

I have no reasons to assume that these are vessels that have a role in an alleged global network of secret CIA-prisons. After concerns about this expressed by the EU, Secretary of State Rice has-repeatedly-guaranteed that the USA does not transport prisoners with the aim of exposing them to torture elsewhere [outside of the USA]. Furthermore, she has stressed that the USA, next to torture, also does not allow cruel, inhumane and humiliating treatment, under no circumstances, wherever in the world, and that goes for anyone who works for the USA (ibid. 1946).

Consequently, no action was taken by the Dutch Foreign Ministry to start an inquiry into the flight data and statistics on CIA-planes that could have used Dutch airspace and airports.

On 17 December 2005, former US Secretary of State, Colin Powell, stated: "the recently highlighted practice of moving people to places where they are not covered by US law, was neither new nor unknown to Europe" (Frost, 2005). Despite Powell confirming Europe knew about the transfers, the Dutch Foreign Ministry did not change its attitude towards possible public inquiries into in ERFs in the Netherlands. Two days later, 19 December 2005, Farah Karimi of the Dutch Green Left party (GroenLinks) asked for information about a landing of a possible CIA-flight at Rotterdam/The Hague Airport (TK, 2005e). This and other questions regarding ERFs in the Netherlands remained unanswered by the cabinet, which "is puzzling [...] 
whereas more information seems to be available", Karimi replied (2006-online).

A couple of months later, on 16 March 2006, three motions were filed during a chamber debate on the CIA-flights (TK, 2006). The first motion was filed by Koenders and Karimi, requesting diplomatic pressure to be put on the US government to disclose information on the transport of prisoners through Dutch airspace. They filed a second motion, to adopt a "code of conduct" for effective surveillance by EU Member States and Eurocontrol on ERFs. The third motion was filed by Lousewies van der Laan, member of the D66, requesting consideration of how to mitigate the reluctant attitude of the US government towards disclosure about the ERP and ERFs. The two motions by Koenders and Karimi were voted against; the motion of Van der Laan was removed from the political agenda entirely, reflecting a silencing of political dissent that is typical, as Chang (2011) notes, for post 9/11 politics. Resulting from the debate, the then State Secretary of Transport, Public Works and Water Management, Karla Peijs, answered the question of whether the flight schedules of alleged CIA-flights that were provided by Eurocontrol contained more information on the boarded passengers. Unfortunately, the exact information on those flight schedules was "state classified", and only shared with the Council of Europe and EP. The only information disclosed during a debate covered (rather generic) flight schedules; information that was no different from information obtained by Dick Marty or what the Dutch Air Traffic Control had. In short, nothing of significance that would raise suspicion was shared.

Normalization of plausible deniability. On 12 November 2007, Chamber Member Alexander Pechtold of the D66 asked several critical questions to Bot's successor, Minister of Foreign Affairs Maxim Verhagen. Pechtold referred to former chief of the CIA Bin Laden Unit, Michael Scheuer, who indicated that the Dutch government already knew in 1995 about the ERP and ERFs, as the Netherlands is one of USA' most important partners (TK, 2007). Verhagen responded that the Netherlands did not actively or passively cooperate in the ERP, and that "the [Dutch] government cannot provide absolute guarantees that the Netherlands has never received information from allies that has been retrieved with the help of torture" (ibid. 1385). Verhagen's claims do not align with Bot's responses in 2005 and 2006 when Bot explicitly and fully denied that the Dutch government was aware of the ERP. Verhagen continued:

The fact that there has been, in general, some knowledge about this instrument [ERP/ERFs], has no bearing on the fact that the Dutch government is not aware of CIA-flights with unlawfully imprisoned suspects of terrorism, happening via Dutch territory. The government has neither actively nor passively assisted in such flights via the Netherlands and does not possess concrete indications that these have happened despite of it (TK, 2007: 1385).

Sir Hans-Gert Pöttering, the then EP President, problematized the indolence of member states towards (investigating) potentially unlawful transfers of detainees via ERFs. This led to further scrutiny of the role of the Dutch government on 3 March 2009 during a meeting of the Dutch Senate's European Cooperation Committee $(\mathrm{ESO})^{3}$ and the Dutch Justice and Home Affairs (JBZ). ${ }^{4}$ Afterward, the ESO and JBZ sent in questions on 24 March 2009 for Verhagen. The official document that contains the questions about the CIA-Rendition program, with proof mark $143316.2 \mathrm{u}$, is no longer available; the questions exist though because they were answered ${ }^{5}$ by Verhagen on 29 June 2009
(Senate, 2009). He reemphasized that the Netherlands is very well aware of its obligations in cases of human rights violations as a result of ERP operations. Moreover, he stated how he and his predecessor Bot in their communication with the USA always condemned transfers of terrorism suspects who had no "adequate legal safeguards" and that the Dutch government respects human rights when fighting terrorism (ibid. 3-4). So, the (facade of) Dutch compliance with that international legality then becomes harmful itself, because it enabled assistance to torture, while the Dutch government was confident it was legally "walking in line" while developing "plausible deniability" of (passive) complicity in torture, as many more democracies tend to do (Conrad et al., 2014). This is further shown by references made by Verhagen to Bot's response in 2005 to Rice's denial of the US' practices of torture, once more stipulating that Bot back then "warmly welcomed" Rice's guarantees that the USA is not involved in practices of torture-a refutation of accusations made against the USA (Senate, 2009).

Both Bot's and Verhagen's narratives do not add up in comparison with each other, and in fact contradict each other. Still they both attempted to create the appearance of how the Netherlands did not know about ERFs. It shows how, despite being suspected of torture complicity, and thus possibly accountable for "bizarre, horrible scenes", "all" they had to do was keep up an appearance of normality" (Cohen, 2002: 81), in this case, not knowing (enough) about ERFs in the Netherlands. So, in normalizing plausible deniability about being neither actively nor passively involved, and despite working along with Marty's investigation, there was no reason to eventually also implement Marty's recommendations to investigate flights through Dutch airspace and landings at airports in the Netherlands to strengthen the national procedures to prevent illegal transfers from happening. However, as Koenders already critically asked on 16 March 2006:

And that's that. Why? How does the cabinet know that it has not been passively complicit? The cabinet has, in compliance with the anti-torture treaty, a task to actively investigate these cases, especially if something is going on. The cabinet actually acknowledges something is going on, because it cooperates in the investigation of Mr Marty. Now, on an international level, everyone seems to wait for everyone; the Council of Europe on the EU Member States and vice versa. That is actually not acceptable any longer (TK, 2006: 59-3816).

The passive complicity Koenders sheds light on, is a type of behaviour that fits the narrative of officially denial provided by the Dutch political elite on: unawareness and unavailability of ERF facts; the (fabricated) acceptance of critique on that ERF narrative; the silencing of dissenting politicians; and, finally, the normalization of plausible deniability regarding ERF involvement. That political denial comes forward from and conceals the colonial past and, especially, colonial present of the Netherlands.

\section{Discussion: Denial of the colonial present}

Since the sixteenth century, Dutch culture has always been praised for its tolerance and liberal values that inspired Enlightenment (Israel, 2004). Yet that culture of tolerance and liberalism stands in stark contrast to colonial atrocities committed by the Dutch East and West Indies Companies (EIC and WIC) during the "Golden Age" (Gouda, 2008) from which that same Enlightenment came. Willem Kieft, a Dutch merchant (Axelrod, 2008) was appointed by the WIC to secure economic prosperity for the Dutch Republic (Churchill, 1997) in New Amsterdam (present- 
day New York). To do so, he had to make the Wappinger indigenous habitants compliant with the Dutch mercantile hunger for natural resources and profiteering, eventually resulting in genocidal violence that led to almost 1000 deaths of Wappinger natives during the 1643 Wappinger War (Schulte-Nordholt, 1966). Part of this "war", was the "Slaughter of the Innocents" in a town called Pavonia where children and women were horrifically executed by WIC troops under Kieft's command. WIC headquarters in Amsterdam wanted Kieft to clarify what happened in Pavonia (Axelrod, 2008: 235-236), which never happened, because on his return to Amsterdam in September 1647, (conveniently) his ship sunk (Murphy, 1854). Comparable are the 1947 and 1949 Dutch massacres, coined "police actions", in Indonesia (a former colony of the Netherlands), leading to about 750 Indonesian deaths for which official apologies follow, more than 60 years later, in 2013 (Vanvugt, 2015). ${ }^{6}$

However, the Dutch government has neither fully officially apologized nor has it been held fully, officially, and thus legally accountable for all its atrocious decolonization violence, despite many initiatives and case-by-case apologies (Vermeulen, 2017). Another example is that of the UN mission of DutchBat III in Srebrenica, during the 1992-95 Bosnian war. Allegedly, by not undertaking any action, DutchBat troops passively assisted the July 1995 genocidal massacre of over a 1000 Muslim Bosniak men by Bosnian Serb troops. On 29 April 2015, the Arnhem Court ruled that the then acting Commander Thom Karremans cannot be prosecuted; Liesbeth Zegveld, lawyer of the Bosniak women and children who survived, intends to make an appeal at the ECtHR (Dzidic, 2015). On 27 June 2017, Presiding Judge DulekSchermers stated that the Dutchbat III soldiers "knew or should have known that the men were not only being screened ... but were in real danger", making the Netherlands "partly liable for the deaths" (Van den Berg, 2017-online source). It took 22 years for relatives to get their victimhood partially recognized, and therefore partially covered (only 30\%) in terms of financial restitution (ibid.); their appeal to hold the Dutch government responsible for failing to protect thousands more Muslims was rejected by the court.

These atrocities may have been (inadvertently) discovered and/ or (partially) acknowledged as such, and (partially) apologized for by the Dutch government. Yet full accountability of (other) colonial bloodshed may (still) be 'displaced, distorted, and (most often) denied, [exposing] the capacities that inhere within the colonial past [and] are routinely reaffirmed and reactivated in the colonial present' (Gregory, 2004: 7). Indeed, the Dutch colonial capacities are reconfigured in the present. Meaning that, although today the Netherlands is celebrated for its lenient drug and prostitution policies, cultural and religious pluralism, LGBT(I) tolerance and rights, and progressive euthanasia approaches (Buruma, 2007), it is, as Cohen notes...

...[i]n more democratic societies [where] official denial is more subtle-putting a gloss on the truth, setting the public agenda, spin-doctoring, tendentious leaks to the media, selective concern about suitable victims, [and] interpretive denials regarding foreign policy [...] built into the ideological facade of the state (2002: 10).

Therefore, the present Dutch colonial capacity (of complicit passivity) is reconfigured not as bluntly in the Golden Age, but rather delicately by the contemporary Dutch political elite; a subtle reconfiguration of present colonialist denial that, as we argue, is reflected in narrating ERF ignorance, silencing disagreeing voices, and normalizing plausible deniability, while conveniently hiding behind the ideological facade of governing a progressive and democratic welfare state.
In conclusion, being in the colonial present while denying it, the Netherlands remains (passively) complicit in gross human rights violations, assisting today's global policing superpowers that outsource: "war crimes to regimes known to practice torture", revealing "the totalizing will to power that lies at the crucial intersections of sovereign power and biopolitics" (Gregory, 2010: 48). The political discourse of ERF denial is the Dutch government's fear of having its modern-day colonial role in the War on Terror exposed (Gregory, 2004), and without being challenged, the Dutch government will keep on "reactivat[ing] the dispositions of a colonial imaginary" (ibid. 260). However, if it wants to confront its colonial past and present, it ought to start an official judicial investigation into its role in ERFs and other alleged colonial aggressions, holding those involved accountable not decades, even centuries post facto, but now. Only then will the Netherlands lead by progressive example, establishing zerotolerance of cruelty that could sanitize what is currently a tainted Dutch tolerance of not just torture but of a variety of colonial atrocities."

\section{Notes}

1 In order to detain and interrogate key al-Qaeda suspects after 9/11, the CIA utilized secret prisons, known as "black sites," where often waterboarding to obtain intelligence was used. It has been claimed that those secret prisons were spread over eight countries and only the US president and a few other officials knew (and could still know) about them (Vitkovskaya, 2017).

2 At Rotterdam/The Hague Airport the following ERF affiliated aircrafts landed; 16 October 2002 an AT43 Aerospatial, number N212AZ; 15 November 2002 an AT43, number N470JF; 27 February 2003 an AT 42, number N315CR; 7 March 2003 an AT 43, number N212AZ; 3 April 2003 an AT 43, number N315CR; and 1 September 2004 an AT 43, number N212AZ. At Princess Juliana International Airport Saint Martin, 15 April 2004 a Gulfstream G 550 plane, number N1HC, landed and allegedly complicit in ERFs.

3 Translated from Dutch: Commissies voor Europese Samenwerkingsorganizaties.

4 Translated from Dutch: Raad Justitie en Binnenlandse Zaken.

5 Whether these were the original questions remains unclear. Perhaps more questions were asked (or less), or asked in a different manner. If anything, the unavailability of the document with the original set of questions is concerning.

6 The irony here is that it was a secret CIA report that described the Dutch police actions in Indonesia, together with the Holocaust and the Great Purge by the Sovie Union, as one of the biggest massacres of the twentieth century (Aarons, 2008: 81).

\section{References}

Aarons M (2008) Justice betrayed: Post-1945 responses to genocide. In: Blumenthal DA and McCormack TLH (eds). The Legacy of Nuremberg: Civilising Influence Or Institutionalised Vengeance? 2008. Martinus Nijhoff: Leiden, pp 69-98.

Alberts J (2005) Regeringen bewust blind voor terroristentransport. Available at: https://www.nrc.nl/nieuws/2005/11/26/regeringen-bewust-blind-voor-terroris tentransport-11048277-a292150.

Alberts J (2006) CIA-vluchten dikwijls via Nederland. Available at: https://www.nrc. nl/nieuws/2006/02/15/cia-vluchten-dikwijls-via-nederland-11083625-a1296091.

Amnesty International. (2006a) Below the radar: Secret flights to torture and "disappearance" Available at: http://www.amnesty.eu/static/documents/2006/ Rendition_report_full_text_05042006.doc.

Amnesty International. (2006b) "Rendition" and secret detention: A global system of human rights violations. Questions and Answers. Available at: https://www. amnesty.org/download/Documents/80000/pol300032006en.pdf.

Amnesty International. (2010) Open Secret: Mounting Evidence of Europe's Complicity in Rendition and Secret Detention. Available at: https:/www. amnesty.org/download/Documents/36000/eur010232010en.pdf.

Amnesty International. (2011) Germany: Briefing to Committee Against Torture Available at: http://www.institut-fuer-menschenrechte.de/fileadmin/user upload/PDF-Dateien/Pakte_Konventionen/CAT/cat_state_report_germany_5_ 2009_parallel_AI_en.pdf.

Aust HP (2013) Complicity and the Law on State Responsibility. Cambridge University Press: Cambridge.

Axelrod A (2008) Profiles in Folly: History's Worst Decisions and Why They Went Wrong. Sterling Publishing: New York, NY.

Bader M and De Jong B (2006) Extraordinary rendition. Een omstreden wapen in terrorismebestrijding. International Spectator; 60 (1): 14-19.

Bakowski P (2012) Extraordinary rendition of terrorism suspects: The EU Member States' alleged assistance to the CIA. Library of the European Parliament. 
Available at: http://www.europarl.europa.eu/RegData/bibliotheque/briefing, accessed 29 April 2014.

Barry J, Hirsch M and Isikoff M (2004) The Roots of Torture. Available at: http:// europe.newsweek.com/roots-torture-128007? $\mathrm{rm}=\mathrm{eu}$.

Blakeley R (2011) Dirty hands, clean conscience? The CIA inspector general's investigation of "enhanced interrogation techniques" in the war on terror and the torture debate. Journal of Human Rights; 10 (4): 544-561.

Blakeley R and Raphael S (2013) Flight Database. Available at: https://www. therenditionproject.org.uk/flights/flight-database.html.

Bodnar A and Pacho I (2012) CIA prisons on polish soil-A new perspective. New Eastern Europe; 4 (3): 78-83.

Boon KE, Huq A and Lovelace DC (2010) Terrorism: Commentary on Security Documents Extraordinary Rendition Vol. 108. Oxford University Press: Oxford.

Bot BR, Kamp HGI and Van Ardenne-Van der Hoeven AMA (2005) Letter to Parliament of the Dutch Minister of Defence Dutch Contribution to ISAF in South-Afghanistan. Available at: https://www.boekje-pienter.nl/images/uruz gan-kamerbrief-22122005.pdf.

Brooks A (2016) The Annihilation of Memory and Silent Suffering: Inhibiting Outrage at the Injustice of Torture in the War on Terror in Australia (doctoral thesis). University of Wollongong: Wollongong.

Brysk A and Shafir G (2007) National Insecurity and Human Rights: Democracies Debate Counterterrorism. University of California Press: London.

Buruma Y (2007) Dutch tolerance: On drugs, prostitution, and euthanasia. Crime and Justice; 35 (1): 73-113

Chang N (2011) Silencing Political Dissent: How Post-September 11 Anti-Terrorism Measures Threaten our Civil Liberties. Seven Stories Press: New York, NY.

CHRGJ. (2014) Rendition Victim Seeks Second Chance at Justice. Available at: http:// chrgj.org/rendition-victim-seeks-second-chance-at-justicecase-against-djiboutidemonstrates-urgent-need-for-transparency-about-cia-rendition-program.

Churchill W (1997) A Little Matter of Genocide: Holocaust and Denial in the Americas, 1492 to the Present. City Lights Books: San Francisco, CA.

Cobain I and Quinn B (2011) How US firms profited from torture flights. Available at: https://www.theguardian.com/world/2011/aug/31/us-firms-torture-flightsrendition.

Cohen S (2002) State of Denial: Knowing about Atrocities and Suffering. Blackwell: Malden, MA.

Conrad C, Hill DW and Moore WH (2014) Political institutions, plausible deniability and the decision to hide torture. SSRN Scholarly Paper ID 248176; 2, 1-57.

Cordell R (2017) Measuring extraordinary rendition and international cooperation. International Area Studies Review 20 (2): 1-9.

Die Welle. (2005) Rice clears air over CIA row in Brussels. Available at: http://www. dw.de/rice-clears-air-over-cia-row-in-brussels/a-1808224.

Diederiks-Verschoor I H Ph (1997) An Introduction to Air Law. Kluwer Law International: Alphen aan den Rijn.

Dimitriu G (2013) Interrogation, coercion and torture: Dutch debates and experiences after 9/11. Intelligence and National Security; 28 (4): $547-565$.

Dimitriu G and De Graaf B (2010) The Dutch COIN approach: three years in Uruzgan, 2006-2009. Small Wars \& Insurgencies; 21 (3): 429-458.

Dzidic D (2015) Dutch Court Rejects Prosecuting Srebrenica Peacekeepers. Available at: http://www.balkaninsight.com/en/article/dutch-court-rules-against-srebre nica-peacekeepers-prosecution.

ECtHR. (2014a) Judgment: Case of al-Nashiri v. Poland (Application No. 28761/11), Strasbourg, 24 July 2014. Available at: http://hudoc.echr.coe.int/eng\#\{"itemid": ["001-146044"]\}.

ECtHR. (2014b) Judgment: Case of Husayn (Abu Zubaydah) v. Poland (Application No. 7511/13), Strasbourg, 24 July 2014. Available at: http://hudoc.echr.coe.int/ eng\#\{"itemid":["001-146047"]\}.

EP. (2012) Resolution of 11 September 2012 on alleged transportation and illegal detention of prisoners in European countries by the CIA: follow-up of the European Parliament TDIP Committee report, 2012/2033. Available at: http:// www.europarl.europa.eu/sides/getDoc.do?type $=$ TA\&reference $=$ P7-TA-20120309\&language $=\mathrm{EN}$

EP. (2015) Parliament to resume investigations into CIA-led operations in EU countries. Available at: http://www.europarl.europa.eu/news/en/news-room/ 20150206IPR21212/parliament-to-resume-investigations-into-cia-led-opera tions-in-eu-countries.

Efrat A (2015) Do human rights violations hinder counterterrorism cooperation? Evidence from the FBI's deployment abroad. The Review of International Organizations; 10 (3): 329-349.

Fava GC (2006) Temporary Committee on the alleged use of European countries by the CIA for the transport and illegal detention of prisoners; Working Document No. 8. Available at: http://www.statewatch.org/cia/documents/working-doc-no8-nov-06.pdf.

Fava GC (2007) Report on the alleged use of European countries by the CIA for the transportation and illegal detention of prisoners. Available at: http://www. europarl.europa.eu/sides/getDoc.do?pubRef $=-/ / \mathrm{EP} / / \mathrm{NONSGML+REPORT}$ $+\mathrm{A} 6-2007-0020+0+\mathrm{DOC}+\mathrm{PDF}+\mathrm{V} 0 / / \mathrm{EN}$.
Feinstein D (2014) Committee Study of the Central Intelligence Agency's Detention and Interrogation Program. Available at: https:/www.amnestyusa.org/pdfs/ sscistudyl.pdf.

Frost D (2005) BBC World TV Interview with General Colin Powell. Available at: http://news.bbc.co.uk/1/hi/programmes/breakfast_with_frost/2228951.stm.

Gregory D (2004) The Colonial Present: Afghanistan, Palestine, Iraq. Blackwell: Oxford.

Gregory D (2010) Vanishing points: Law, violence, and exception in the global war prison. In: Boehmer E and Morton S (eds). Terror and the Postcolonial: A Concise Companion. Wiley: Oxford, pp 55-98.

Gouda F (2008) Dutch Culture Overseas: Colonial Practice in The Netherlands Indies, 1900-1942. Equinox: Amsterdam.

Hawkins KR (2005) The promises of torturers: diplomatic assurances and the legality of rendition. Georgetown Immigration Law Journal; 20, 213-268.

Herman ES and Chomsky N (2010) Manufacturing Consent: The Political Economy of the Mass Media. Random House: London.

House of Commons Foreign Affairs Committee. (2009) Human Rights Annual Report 2008: Seventh Report of Session 2008-09 Report. Available at: https:// www.publications.parliament.uk/pa/cm200809/cmselect/cmfaff/557/557.pdf.

HRW. (2012) Delivered Into Enemy Hands: US-Led Abuse and Rendition of Opponents to Gaddafi's Libya. Available at: http://www.refworld.org/docid/ 5049cele2.html.

ICJ. (2007) Reports of Judgements, Advisory Opinions and Orders Case Concerning Application of the Convention on the Prevention and Punishment of the Crime of Genocide (Bosnia Herzegovina v. Serbia and Montenegro) Judgement of 26 February 2007. Available at http://www.icj-cij.org/docket/files/91/13685.pdf.

Israel JI (2004) Bayle, Enlightenment, Toleration and Modern Western Society. Pierre Bayle Lecture, 11 December 2004. Available at: http://www.pierrebayle.nl/ lezingen/jonathan-israel/.

Johnson D, Mora A and Schmidt A (2016) The strategic costs of torture: How enhanced interrogation hurt America. Foreign Affairs; 95 (5): 121-132.

Karimi F (2006) CIA-vluchten: Bot moet zich verantwoorden over geheimhouden informatie. Available at: https://groenlinks.nl/nieuws/cia-vluchten-bot-moetzich-verantwoorden-over-geheimhouden-informatie.

Kempner J, Merz JF and Bosk CL (2011) Forbidden knowledge: Public controversy and the production of nonknowledge. Sociological Forum; 26 (3): 475-500.

Marty D (2007) Secret detentions and illegal transfers of detainees involving Council of Europe member states: second report. Available at: http://assembly.coe.int/ CommitteeDocs/2007/EMarty_20070608_NoEmbargo.pdf.

Mayer J (2005) Outsourcing Torture: The Secret History of America's "Extraordinary Rendition" Program. Available at: www.newyorker.com/printables/ fact/050214fa_fact6.

MERLN. (2005) Secretary Condoleezza Rice, Remarks Upon Her Departure for Europe. Available at: http://merln.ndu.edu/archivepdf/terrorism/state/57602. pdf.

Messineo F (2009) Extraordinary renditions and state obligations to criminalize and prosecute torture in the light of the Abu Omar case in Italy. Journal of International Criminal Justice; 7 (5): 1023-1044.

Milde M (2008) Rendition flights and International air law. German Journal of Air and Space Law; 57 (4): 477-486.

Modvig J, Jaranson JM (2004) A global perspective of torture, political violence, and health. In: Wilson JP and Drozdek B (eds). Broken Spirits: The Treatment of Traumatized Asylum Seekers, Refugees and War and Torture victIms 2004. Routledge: London, pp 33-52.

Murphy HC (1854) Vertoogh van Nieu Nederland en Breeden raedt. Koninklijke Bibliotheek: Den Haag.

NATO. (2001) Press Release of NATO Secretary General, Lord Robertson Speech, on the North Atlantic Council Decision on Implementation of Article 5 of the Washington Treaty following the 11 September Attacks against the United States. Available here: http://dipbt.bundestag.de/dip21/btd/17/CD07400/Dokumente/ Dokument\%20024.pdf.

NATO. (2005) Foreign Ministers meetings Media Advisory-Brussels, 8 December 2005. Available at: http://www.nato.int/cps/en/natolive/news_21362.htm?selec tedLocale $=$ en.

Nowak M (2008) Preface. In: ECCHR (ed). CIA 'Extraordinary Rendition' Flights, Torture and Accountability: A European Approach. ECCHR: Berlin, pp 9-513.

OSJI. (2013) Globalizing Torture: CIA Secret Detention and Extraordinary Rendition. Available at: http://www.opensocietyfoundations.org.

Parlement en Politiek. (2006) Besluitvorming ISAF-missie Afghaanse provincie Uruzgan. Available at: http://www.parlement.com/id/vhnnmt7lkh3r/besluit vorming_isaf_missie_afghaanse.

Passas N (2005) Lawful but awful: 'Legal corporate crimes'. The Journal of Socioeconomics; 34 (6): 771-786.

Priest D and Gellman B (2002) US Decries Abuse but Defends Interrogations. Available at: http://www.washingtonpost.com.

Raphael S, Black C, Blakeley R and Kostas S (2016) Tracking rendition aircraft as a way to understand CIA secret detention and torture in Europe. The International Journal of Human Rights; 20 (1): 78-103. 
The Rendition Project. (2002) Contribution of the Rapporteur. Research on the planes used by the CIA. Available at: https://www.therenditionproject.org.uk/ pdf/PDF\%20146\%20[Fava\%20Report,\%20Research\%20and\%20Flight\%20Data \%20on\%20CIA\%20Planes].pdf.

The Rendition Project. (2010a) OSJI and HFHR, Explanation of Rendition Flight Records Released by the Polish Air Navigation Services Agency. Available at: http://www.therenditionproject.org.uk/documents/RDI/100222-OSJI-HFHR Poland_FOI_Flight_Data_Explanation.pdf.

The Rendition Project. (2010b) Rendition Circuits. Available at: http://www. therenditionproject.org.uk/flights/renditions/index.html.

Said E (2003) The academy of Lagado. London Review of Books; 25 (8): 39.

Satterthwaite ML (2007) Rendered meaningless: Extraordinary rendition and the rule of law. George Washington Law Review; 75 (5/6): 6-36.

Satterthwaite ML (2008) The U.S. Program of extraordinary rendition and secret detention: Past and future. In: ECCHR (ed). CIA 'Extraordinary Rendition' Flights, Torture and Accountability: A European Approach. ECCHR: Berlin, pp 27-58.

Scahill J (2013) Dirty Wars: The World is a Battlefield. Serpents Tail: London.

Schulte-Nordholt JW (1966) Nederlanders in Nieuw Nederland. De oorlog van Kieft. Koninklijke Bibliotheek: Den Haag.

Senate. (2009) Beantwoording vragen van de Vaste Commissie voor Europese Samenwerkingsorganisaties en voor de JBZ-Raad over het CIA Rendition Programma. Available at: http://www.eerstekamer.nl/eu/behandeling/20090629/ brief_minister_met_toelichting.

Shubber S (1973) Jurisdiction Over Crimes on Board Aircraft. Martinus Nijhoff: The Hague.

Sturcke J (2006) EU report condemns secret CIA flights. Available at: https://www. theguardian.com/world/2006/apr/26/eu.politics1.

Tombs S and Whyte D (2003) Unmasking the crimes of the powerful. Critical Criminology; 11 (3): 217-236.

TK. (2005a) Aanhangsel Handelingen II, 2005-2006, nr. 656. Available at: http:// parlis.nl/pdf/kamervragen/KVR24650.pdf.

TK. (2005b) Bestrijding internationaal terrorisme. Kamerstukken II 2005-2006, T 27 925, nr. 193. Available at: http://www.parlement.com/9291000/d/uruzganbe sluit_2005.pdf.

TK. (2005c) Aanhangsel Handelingen II, 2005-2006, nr. 754. Available at: http:// parlis.nl/pdf/kamervragen/KVR24764.pdf.

TK. (2005d) Aanhangsel Handelingen II, 2005-2006, nr. 918. Available at: http:// parlis.nl/pdf/kamervragen/KVR24961.pdf.

TK. (2005e) Aanhangsel Handelingen II, 16 December 2005, nr. kv-2050605000. Available at: https://zoek.officielebekendmakingen.nl/kv-2050605000.html.

TK. (2005f) Aanhangsel Handelingen II, 24 February 2005, nr. kv-2040505840. Available at: http://parlis.nl/pdf/kamervragen/KVR22295.pdf.

TK. (2005g) Aanhangsel Handelingen II, 25 April 2005, nr. kv-2040510350. Available at: http://parlis.nl/pdf/kamervragen/KVR22831.pdf.

TK. (2006) Aanhangsel Handelingen II, 2005-2006, nr. 59. Available at: http://zoek. officielebekendmakingen.nl/h-tk-20052006-3815-3837.pdf.

TK. (2007) Aanhangsel Handelingen II, 2007-2008, nr. 648. Available at: http:// parlis.nl/pdf/kamervragen/KVR30127.pdf.

Trouw. (2005a) PvdA wil onderzoek naar CIA-vluchten 19 November 2005, http:// www.trouw.nl/tr/nl/4324/Nieuws/archief/article/detail/1721437/2005/11/19/ PvdA-wil-onderzoek-naar-CIA-vluchten.dhtml.

Trouw. (2005b) Rice neemt bezorgdheid Bot en De Hoop Scheffer weg. Available at: https://www.trouw.nl/home/rice-neemt-bezorgdheid-bot-en-de-hoop-schefferweg $\sim \operatorname{acd} 2 \mathrm{ec} 9 \mathrm{~b} /$.

Trouw. (2007) EU-lidstaten wisten van geheime CIA-vluchten. Available at: https:// www.trouw.nl/home/eu-lidstaten-wisten-van-geheime-cia-vluchten $\sim$ a961fa7b/.

UK Joint Committee on Human Rights. (2006) The UN Convention Against Torture (UNCAT)' Nineteenth Report of Session 2005-06 Volume I-Report and formal minutes HL Paper 185-I HC 701-I. Available at: http://www.publications. parliament.uk/pa/jt200506/jtselect/jtrights/185/185-i.pdf.

UN. (1944) Convention on Civil Aviation (Chicago Convention). Available at: http://www.icao.int/publications/Documents/7300_orig.pdf.

UN. (1963) Convention on Offences and Certain Other Acts Committed On Board Aircraft (Tokyo Convention). Available at: https://treaties.un.org/doc/db/terror ism/conv1-english.pdf.

UNHRC. (2010) Joint study on Global Practices in Relation to Secret Detention in the Context of Countering Terrorism of the Special Rapporteur on the Promotion and Protection of Human Rights and Fundamental Freedoms While
Countering Terrorism. Available at: http://hrlibrary.umn.edu/instree/A-HRC13-42.pdf.

UNHRC. (1977) Note on Non-Refoulement (Submitted by the High Commissioner) EC/SCP/2. Available at: http://www.UNHRC.org/uk/excom/scip/3ae68ccd10/ note-non-refoulement-submitted-high-commissioner.html.

Van Boven T (2002) Interim Report of the Special Rapporteur on Torture to the General Assembly. Available at: http://www.statewatch.org/news/2004/nov/untorture-doc3.pdf.

Vanvugt E (2015) Roofstaat: wat iedere Nederlander moet weten. Nijgh \& Van Ditmar: Amsterdam.

Van den Berg S (2017) Court confirms Dutch U.N. peacekeepers partly liable for Srebrenica massacre. https://www.reuters.com/article/us-warcrimes-bosnia-sreb renica-idUSKBN19I0XZ.

Venice Commission. (2006) On the International Legal Obligations of Council of Europe Member States in Respect of Secret Detention Facilities and Inter-State Transport of Prisoners. Available at: http://www.venice.coe.int/webforms/ documents/default.aspx?pdffile $=$ CDL-AD(2006)009-e.

Vermeulen F (2017) Nederland moet handelen naar aansprakelijkheid. https:// www.nrc.nl/nieuws/2017/01/29/nederland-moet-handelen-naar-aansprakelijk heid-6462575-a1543534.

Vitkovskaya J (2017) What are 'black sites?' 6 key things to know about the CIA's secret prisons overseas. Available at: https://www.washingtonpost.com/news/ checkpoint/wp/2017/01/25/what-are-black-sites-6-key-things-to-know-aboutthe-cias-secret-prisons-overseas/?utm_term $=$.eadf75e86bbc.

Volkskrant. (2005a) Bot niet tevreden over antwoorden Rice. Available at: http:// www.volkskrant.nl/binnenland/bot-niet-tevreden-over-antwoorden-rice a684419/.

Volkskrant. (2005b) Onderzoek CIA-vlucht op Schiphol. Available at http://www. volkskrant.nl/vk/nl/2686/Binnenland/article/detail/681900/2005/11/21/Onder zoek-lsquo-CIA-vlucht-rsquo-op-Schiphol.dhtml.

Waterman S (2005) Terror Detainees Sent to Egypt; Official, U.S. Deny Torture is Condoned. Washington Times. Available at: http://www.washingtontimes.com/ news/2005/may/15/20050515-115906-5452r/.

Zembla. (2005) The Secret CIA-flights. Available at http://zembla.incontxt.nl.

\section{Data availability}

Data sharing is not applicable to this article as no datasets were generated or analysed during the current study.

\section{Acknowledgements}

The authors would like to thank Lucinda Thompson for her helpful and insightful comments on earlier versions of this article.

\section{Additional information}

Competing interests: The authors declare that they have no competing financial interests.

Reprints and permission information is available at http://www.palgrave-journals.com/ pal/authors/rights_and_permissions.html

How to cite this article: Eski S and Eski Y (2017) Dutch tolerance of torture? CIA extraordinary rendition flights in the Netherlands. Palgrave Communications. 3:17084 doi: $10.1057 /$ palcomms.2017.84.

Publisher's note: Springer Nature remains neutral with regard to jurisdictional claims in published maps and institutional affiliations.

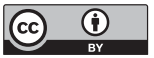

This work is licensed under a Creative Commons Attribution 4.0 International License. The images or other third party material in this article are included in the article's Creative Commons license, unless indicated otherwise in the credit line; if the material is not included under the Creative Commons license, users will need to obtain permission from the license holder to reproduce the material To view a copy of this license, visit http://creativecommons.org/licenses/by/4.0/

(C) The Author(s) 2017 